\title{
Difference in the late ergosterol biosynthesis between yeast spheroplasts and intact cells
}

\author{
Terenzio Ferrante, Franca Viola, Gianni Balliano and Simonetta Oliaro-Bosso ${ }^{\bowtie}$ \\ University of Torino, Department of Drug Science and Technology, Torino, Italy
}

\begin{abstract}
A comparative study on post-squalene sterol synthesis in intact yeast cells and spheroplasts was carried out with strains from three genera (Saccharomyces cerevisiae, Schizosaccharomyces pombe, Pichia pastoris) as well as with engineered $S$. cerevisiae cells altered in regard to the late ergosterol synthesis pathway. A common outcome of incubation experiments with radioactive acetate was that in intact cells the metabolic pathway flows till its specific end product (ergosterol and its precursor, depending on the enzyme deficiency), whereas in spheroplasts the pathway was stalled some step upstream. For example, in spheroplasts from wt strains, non-cyclic triterpenes squalene and oxidosqualene accumulated as though the metabolic path was kept from producing steroid-shaped molecules different from the end product. Accumulation of non-cyclic triterpenes was observed also in spheroplasts from S. cerevisiae cells lacking 3-ketosteroid reductase activity, an enzyme belonging to the C4-demethylase complex. When production of cyclic triterpenes was compromised by loss or poor functionality of oxidosqualene cyclase (EC 5.4.99.7), the difference between intact cells and spheroplasts was still remarkable, yet limited to the different oxido/dioxidosqualene ratio. The characteristics of spheroplasts as non-proliferating cells may partially explain the observed differences in post-squalene pathway from intact cells. We cannot say if the difference in metabolic pathways in spheroplasts and intact cells is a rule. We think, however, that it is worthwhile to search for an answer, as a wider picture of the points where the metabolic pathways are stalled in spheroplasts could provide original ideas about the metabolic network in yeast.
\end{abstract}

Key words: yeast cell wall, spheroplasts, late sterol biosynthesis, engineered yeast strains, Erg27p, Erg7p

Received: 24 November, 2015; revised: 28 December, 2015;

accepted: 30 December, 2015; available on-line: 31 March, 2016

\section{INTRODUCTION}

Yeast spheroplasts created from intact cells by lytic digestion of the cell wall (Daum et al., 1982) provide a useful model to study in eukaryotes the effect of compounds that are blocked by the presence of the cell wall (Becker \& Schmitt, 2011). For instance, if the molecules are designed as inhibitors of metabolic pathways occurring in mammalian cells, preliminary studies can be carried out with the yeast spheroplasts, which mimic intact mammalian cells in being separated from the medium only by the plasma membrane. Spheroplasts may prove to be useful also in studies aimed at designing anti-parasitic/anti-protozoarian molecules, where the ability of the designed molecule to enter the intact cell and reach the target enzyme has to be assayed (Oliaro-Bosso et al., 2004). In this case, the yeast spheroplasts prepared from engineered yeast cells expressing the parasite/protozoan target enzyme roughly mimic the single cells of the unicellular organism, although in a non-proliferating state. In a study aimed at designing new anti-Trypanosoma molecules, we used yeast (Saccharomyces cerevisiae) cells expressing Trypanosoma oxidosqualene cyclase (OSC, EC 5.4.99.7), the target enzyme, as a preliminary in vitro model (Balliano et al., 2009). As we knew from previous experiments, that Trypanosoma OSC perfectly complements yeast OSC in sterol biosynthesis (Milla et al., 2002a; Oliaro-Bosso et al., 2004), we expected to observe in control (non-treated) spheroplasts incubated with radiolabelled acetate approximately the same distribution of radioactive post-squalene lipids as detected in intact cells,

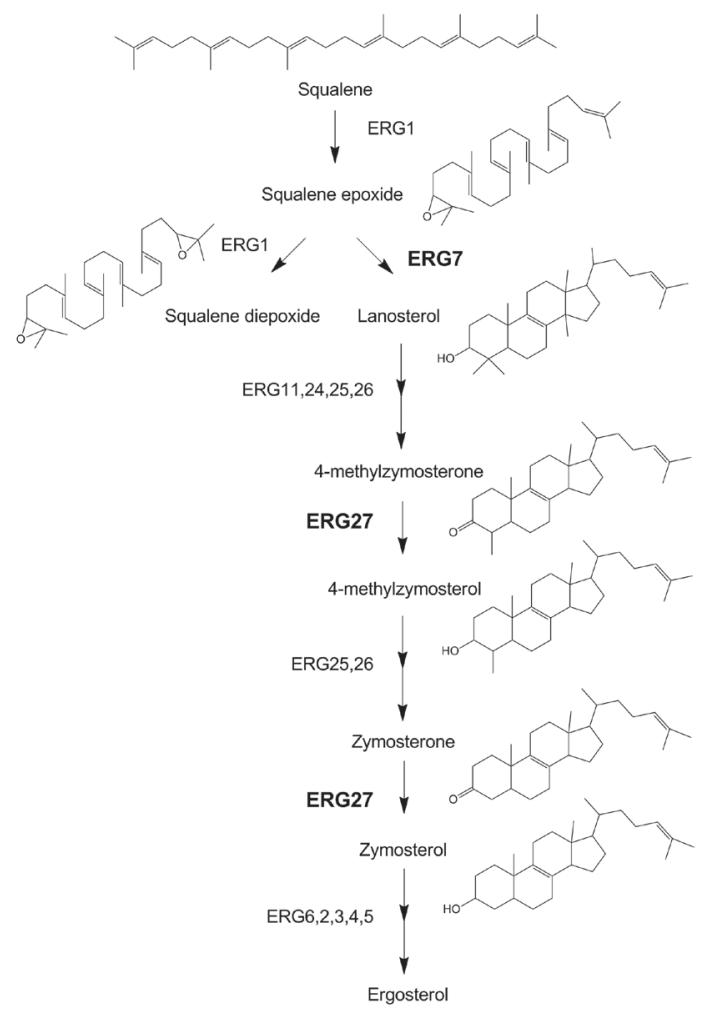

Figure 1. Post-squalene pathway in S. cerevisiae In bold, the mutant steps in the strains used in this work.

e-mail: simona.oliaro@unito.it

Abbreviations: OSC, oxidosqualene cyclase; Erg7p, oxidosqualene cyclase; Erg27p, 3-ketosteroid reductase; DOS, dioxidosqualene 
Table 1. Yeast strains used in this study

\begin{tabular}{|c|c|c|}
\hline Strains & Genotype & Source \\
\hline \multicolumn{3}{|l|}{ S. cerevisiae } \\
\hline SCY876 (wt) & MATa, upc2-1, hap1Ty, ura3, his3, leu2, trp1 & (Taramino et al., 2010a) \\
\hline STY2 (erg7 $\Delta)$ & $\begin{array}{l}\text { MATa, upc2-1, hap 1Ty, ura3, his3, leu2, trp1, } \\
\text { erg7 }:: \text { HIS3 }\end{array}$ & (Taramino et al., 2010a) \\
\hline BTY6-5-3 (erg27 4$)$ & $\begin{array}{l}\text { MATa, upc2-1, hap 1Ty, ura3, his3, leu2, trp1, } \\
\text { erg27 }:: \text { LEU2 }\end{array}$ & (Taramino et al., 2010b) \\
\hline BTY6-5-3 (K206A-Erg27p) & $\begin{array}{l}\text { MATa, upc2-1, hap 1Ty, ura3, his3, leu2, trp1, } \\
\text { erg27-K206A }\end{array}$ & (Teske et al., 2008) \\
\hline BTY6-5-3 (R40A-Erg27p) & $\begin{array}{l}\text { MATa, upc2-1, hap 1Ty, ura3, his3, leu2, trp1, } \\
\text { erg27-R40A }\end{array}$ & (Teske et al., 2008) \\
\hline S. pombe KGY425 (wt) & h-, his3-D1, leu1-32, ura4-D18, ade6-M210 & $\begin{array}{l}\text { Prof. P. Espenshade (Department of Cell Biology, Johns } \\
\text { Hopkins University School of Medicine, Baltimore, Maryland } \\
\text { 21205, United States) }\end{array}$ \\
\hline P. pastoris GS115 (wt) & his4 & Life Technologies \\
\hline
\end{tabular}

namely most radioactivity accumulated into ergosterol, the end product of the pathway. Surprisingly, the lipid composition in spheroplasts was dramatically different, being ergosterol a minor fraction, while most radioactivity accumulated into squalene, a non-cyclic triterpene of the sterol biosynthetic pathway. Results suggested carrying out a careful comparative study of the metabolic fate of post-squalene pathway (Fig. 1) in yeast intact cells and spheroplasts, and to extend the study to other unicellular cell wall-equipped eukaryotes such as Pichia pastoris and Schizosaccaromyces pombe. The study was completed by using engineered yeast strains altered in regard to the post squalene section of ergosterol biosynthesis. Tracer experiments with radioactive acetate revealed that the main difference between intact cells and spheroplasts, irrespective of the organism used, was the accumulation of noncyclic precursor of ergosterol, squalene and oxisqualene. The differences observed suggest that a deep metabolic rearrangement might occur within other pathways of the lipid metabolism when cells are deprived of their cell wall.

\section{MATERIALS AND METHODS}

Chemicals. Solvents, buffers, culture media and ergosterol were purchased from Sigma-Aldrich (Italy). $\left[2-{ }^{14} \mathrm{C}\right]$ acetic acid $(2.04 \mathrm{GBq} / \mathrm{mmol})$ was purchased from Perkin Elmer Italia SpA (Italy).

Yeast strains and culture conditions. The strains used in this study are listed in Table 1.

Both P. pastoris GS115 and S. cerevisiae SCY876 wildtype strains were grown to early stationary phase at $30^{\circ} \mathrm{C}$ in YPD medium $(1 \%, \mathrm{w} / \mathrm{v}$, yeast extract, $2 \%, \mathrm{w} / \mathrm{v}$, peptone, $2 \%$, w/v, glucose). The $S$. pombe KGY425 wildtype strain was grown to early stationary phase at $30^{\circ} \mathrm{C}$ in YD medium $(0.5 \%$, w/v, yeast extract, 3\%, w/v, glucose) supplemented with $0.225 \mathrm{mg} / \mathrm{mL}$ each of histidine, leucine, adenine, lysine and uracil.

$S$. cerevisiae deletant mutant strains for either ERG7 (STY2) or ERG27 (BTY6-5-3) were grown to early stationary phase at $30^{\circ} \mathrm{C}$ in YPD medium, supplemented with ergosterol (0.02 mg/mL). S. cerevisiae K206A-Erg27p and R40A-Erg $27 \mathrm{p}$ mutant strains were grown at $30^{\circ} \mathrm{C}$ in synthetic complete medium without uracil SC-UraD $(0.17 \%, \mathrm{w} / \mathrm{v}$, yeast nitrogen base, $0.2 \%, \mathrm{w} / \mathrm{v}$, amino acids, $0.5 \%, \mathrm{w} / \mathrm{v}$, ammonium sulphate, $2 \%, \mathrm{w} / \mathrm{v}$, glucose), supplemented with ergosterol (0.02 $\mathrm{mg} / \mathrm{mL})$. STY2,
BTY6-5-3, K206A-Erg27p and R40A-Erg27p strains were also able to grow under aerobic conditions with sterol supplementation because they contain the allele upc2-1, that allows aerobic sterol uptake (Wilcox et al., 2002).

Incorporation of $\left[2-{ }^{-14} \mathrm{C}\right]$ acetate into the non-saponifiable lipids of whole yeast cells. The incorporation of $\left[2-{ }^{14} \mathrm{C}\right]$ acetate in whole yeast cells was performed as described previously (Balliano et al., 1988). Briefly, washed cells $\left(1 \times 10^{8}\right.$ cells $)$ were resuspended in $1 \mathrm{~mL}$ of fresh media and incubated with $0.1 \mu \mathrm{Ci}$ of $\left[2-{ }^{14} \mathrm{C}\right] \mathrm{ac}-$ etate in presence of Tween-80 $(0.2 \mathrm{mg} / \mathrm{mL})$. Cells were shaken for $3 \mathrm{~h}$ at $30^{\circ} \mathrm{C}$, then saponified in $1 \mathrm{~mL}$ of methanolic $\mathrm{KOH}\left(15 \%\right.$, w/v) for $30 \mathrm{~min}$ at $80^{\circ} \mathrm{C}$. Nonsaponifiable lipids were extracted twice with $1.5 \mathrm{~mL}$ of petroleum ether and separated on silica gel TLC plates $(20 \times 20 \mathrm{~cm} \times 0.25 \mathrm{~mm})$ (Macherey-Nagel, Germany), using cyclohexane/ethyl acetate $(85: 15, \mathrm{v} / \mathrm{v})$. Squalene, oxidosqualene, dioxidosqualene, lanosterol and ergosterol were used for reference. Radioactivity in separated bands was determined using a System 200 Imaging Scanner (Hewlett-Packard, Palo Alto, CA, USA).

Chemical reduction of radioactive non-saponifiable lipids of the S. cerevisiae K206A-Erg27p mutant strain with $\mathrm{NaBH}_{4}$. The ketonic nature of the compounds was established by treatment with $\mathrm{NaBH}_{4}$ (Sigma-Aldrich, Italy) (Taramino et al., 2010a). An aliquot of petroleum extract was then incubated with $5 \mathrm{mg}$ of $\mathrm{NaBH}_{4}$ in $1 \mathrm{~mL}$ of ethanol for $30 \mathrm{~min}$ with magnetic stirring. The reaction was stopped by adding $1 \mathrm{~mL}$ of water, and the reaction mixture was extracted twice with $1 \mathrm{~mL}$ of petroleum ether and separated on silica gel TLC plates $(20 \times 20 \mathrm{~cm} \times 0.25 \mathrm{~mm})$ (Macherey-Nagel, Germany), using cyclohexane/ethyl acetate $(85: 15, \mathrm{v} / \mathrm{v})$.

Incorporation of $\left[2-{ }^{14} \mathrm{C}\right]$ acetate into the non-saponifiable lipids of spheroplast yeast cells. The incorporation of $\left[2-{ }^{14} \mathrm{C}\right]$ acetate in spheroplasts was performed as described previously (Oliaro-Bosso et al., 2004). Briefly, the spheroplasts $\left(3 \times 10^{8}\right.$ cells $)$, obtained by lysing the cell walls with lyticase (Sigma-Aldrich, Italy) (Daum et al., 1982), were resuspended in $2.5 \mathrm{~mL}$ of $20 \mathrm{mM}$ phosphate buffer, $\mathrm{pH} 7.4$, containing $1.2 \mathrm{M}$ sorbitol, 1\% (w/v) glucose, and incubated, in presence of Tween- 80 (0.2 mg/ $\mathrm{mL})$, with $0.25 \mu \mathrm{Ci}$ of $\left[2-{ }^{14} \mathrm{C}\right]$ acetate. Spheroplasts were shaken for $2 \mathrm{~h}$ at $30^{\circ} \mathrm{C}$, then saponified in $1 \mathrm{~mL}$ of methanolic $\mathrm{KOH}\left(15 \%\right.$, w/v) for $30 \mathrm{~min}$ at $80^{\circ} \mathrm{C}$. The extraction and analysis of non-saponifiable lipids were performed as previously reported. 
Table 2. $\left[2-{ }^{14} \mathrm{C}\right]$ acetate incorporation into the non-saponifiable lipid fraction of yeast wild-type strains, S. cerevisiae ERG7 and ERG27 deletant strains, S. cerevisiae ERG27 mutant strains.

\begin{tabular}{|c|c|c|c|c|c|c|c|c|c|c|}
\hline \multirow{2}{*}{ Strain } & \multicolumn{10}{|c|}{$\%$ total radioactivity incorporated } \\
\hline & $\mathrm{S}$ & OS & 4-MMS & DOS & 4,4-DMS & $\mathrm{X}$ & $\mathrm{L}$ & 4-MM Sterols & $\mathrm{E}$ & OS/ DOS \\
\hline $\begin{array}{l}\text { S. cerevisiae } \\
\text { SCY876 } \\
\text { whole cell } \\
\text { spheroplast }\end{array}$ & $\begin{array}{l}18.59 \\
21.96\end{array}$ & $\begin{array}{l}* \\
13.38 \\
54.05\end{array}$ & - & $\begin{array}{l}1.31 \\
0.28\end{array}$ & - & $\begin{array}{l}- \\
-\end{array}$ & $\begin{array}{l}9.93 \\
8.48\end{array}$ & $\begin{array}{l}4.01 \\
2.79\end{array}$ & $\begin{array}{l}* \\
52.78 \\
12.44\end{array}$ & $\begin{array}{l}10.21 \\
193.03\end{array}$ \\
\hline $\begin{array}{l}\text { S. pombe } \\
\text { KGY425 } \\
\text { whole cell } \\
\text { spheroplast }\end{array}$ & $\begin{array}{l}22.42 \\
17.33\end{array}$ & $\begin{array}{l}* \\
12.69 \\
61.42\end{array}$ & - & $\begin{array}{l}1.09 \\
0.75\end{array}$ & - & - & $\begin{array}{l}13.75 \\
10.23\end{array}$ & $\begin{array}{l}2.77 \\
3.05\end{array}$ & $\begin{array}{l}* \\
47.28 \\
7.22\end{array}$ & $\begin{array}{l}11.64 \\
81.89\end{array}$ \\
\hline $\begin{array}{l}\text { P. pastoris } \\
\text { GS115 } \\
\text { whole cell } \\
\text { spheroplast }\end{array}$ & $\begin{array}{l}2.92 \\
4.01\end{array}$ & $\begin{array}{l}* \\
4.12 \\
61.38\end{array}$ & - & $\begin{array}{l}0.71 \\
0.69\end{array}$ & - & - & $\begin{array}{l}2.01 \\
3.42\end{array}$ & $\begin{array}{l}4.35 \\
2.40\end{array}$ & $\begin{array}{l}* \\
85.89 \\
28.10\end{array}$ & $\begin{array}{l}5.80 \\
88.92\end{array}$ \\
\hline $\begin{array}{l}\text { STY2 (erg7D) } \\
\text { whole cell } \\
\text { spheroplast }\end{array}$ & $\begin{array}{l}* \\
0.67 \\
5.22\end{array}$ & $\begin{array}{l}* \\
20.12 \\
73.15\end{array}$ & - & $\begin{array}{l}* \\
77.68 \\
19.40\end{array}$ & - & - & $\begin{array}{l}0.36 \\
0.40\end{array}$ & - & $\begin{array}{l}1.17 \\
1.83\end{array}$ & $\begin{array}{l}0.26 \\
3.77\end{array}$ \\
\hline $\begin{array}{l}\text { BTY6-5-3 (erg27D) } \\
\text { whole cell } \\
\text { spheroplast }\end{array}$ & $\begin{array}{l}* \\
2.02 \\
8.21\end{array}$ & $\begin{array}{l}* \\
19.03 \\
80.12\end{array}$ & $\begin{array}{l}- \\
-\end{array}$ & $\begin{array}{l}* \\
77.18 \\
8.53\end{array}$ & - & - & $\begin{array}{l}0.64 \\
0.91\end{array}$ & - & $\begin{array}{l}1.13 \\
2.23\end{array}$ & $\begin{array}{l}0.25 \\
9.39\end{array}$ \\
\hline $\begin{array}{l}\text { R40A-Erg27p } \\
\text { whole cell } \\
\text { spheroplast }\end{array}$ & $\begin{array}{l}* \\
4.33 \\
39.33\end{array}$ & $\begin{array}{l}* \\
5.27 \\
11.44\end{array}$ & $\begin{array}{l}40.97 \\
27.54\end{array}$ & $\begin{array}{l}1.01^{*} \\
0.42^{*}\end{array}$ & $\begin{array}{c}22.95 \\
4.39\end{array}$ & $\begin{array}{l}9.71 \\
5.58\end{array}$ & $\begin{array}{l}4.56 \\
5.15\end{array}$ & $\begin{array}{l}4.24 \\
1.91\end{array}$ & $\begin{array}{l}6.96 \\
4.24\end{array}$ & $\begin{array}{l}5.21 \\
27.24\end{array}$ \\
\hline $\begin{array}{l}\text { K206A-Erg27p } \\
\text { whole cell } \\
\text { spheroplast }\end{array}$ & $\begin{array}{l}* \\
4.02 \\
20.53\end{array}$ & $\begin{array}{l}* \\
6.18 \\
13.21\end{array}$ & $\begin{array}{l}30.06 \\
34.92\end{array}$ & $\begin{array}{l}2.22 \\
1.13\end{array}$ & $\begin{array}{c}27.24 \\
9.45\end{array}$ & $\begin{array}{c}11.30 \\
7.56\end{array}$ & $\begin{array}{l}5.65 \\
6.12\end{array}$ & $\begin{array}{l}5.76 \\
2.21\end{array}$ & $\begin{array}{l}7.57 \\
4.87\end{array}$ & $\begin{array}{l}2.78 \\
11.69\end{array}$ \\
\hline
\end{tabular}

S: squalene; OS: oxidosqualene; 4-MMS: 4-monomethylsterones (compounds chromatographically corresponding to 4-methylzymosterone); DOS: dioxidosqualene; 4,4-DMS: 4,4-desmethylsterones (compounds chromatographically corresponding to zymosterone); L: lanosterol; 4-MMSterols: 4-monomethylsterols (TLC bands with Rf values ranging from lanosterol to ergosterol); E: ergosterol; X: compound not identified. *An asterisk indicates a significant difference $(\mathrm{P}<0.05)$ between the proportion of radioactivity incorporated into whole cells and spheroplasts (two tailed t-test). Whole and spheroplast yeast cells were incubated with $\left[2-{ }^{14} \mathrm{C}\right]$ acetate in presence of Tween-80 for 3 and $2 \mathrm{~h}$ at $30^{\circ} \mathrm{C}$, respectively, then saponified for $30 \mathrm{~min}$ at $80^{\circ} \mathrm{C}$. Non-saponifiable lipids were extracted with petroleum ether and separated on silica gel TLC plates.

Statistical analysis. Results are the means of at least three experiments, each with duplicate incubations.

Prior to statistical analysis, percentages $(\%)$ of incorporation in each product or group of products have been transformed to the arcsin $(\%)^{0.5}$ in order to stabilize the variance. Transformed data were compared by the one-tailed $t$-test with unequal variances.

\section{RESULTS}

To compare sterol biosynthesis in yeast cells and spheroplasts, we traced the distal section of ergosterol biosynthesis by incubating either intact cells or spheroplasts of $S$. cerevisiae, $S$. pombe and $P$. pastoris with radiolabelled acetate. Spheroplasts from $P$. pastoris and $S$. pombe were prepared through a procedure developed for $S$. cerevisiae (Daum et al., 1982). After incubation, cultures containing either cells or spheroplasts were directly saponified, and non-saponifiable lipids were separated by TLC. The distribution of radioactivity among the non-saponifiable lipids was then detected by radioscanning the TLC plates.

\section{Intact cells and spheroplasts from wt strains of $S$. cerevisiae, S. pombe and $P$. pastoris}

A notable difference between intact cells and spheroplasts, shared by all three organisms, was that in intact cells most radioactivity accumulated into ergosterol, the end product of the pathway, whereas in spheroplasts the non-cyclic squalene-type intermediates kept the bulk $(>60 \%)$ of the radioactivity of the non-saponifiable fraction. In the spheroplasts, however, the metabolic flow toward the end product was not completely blocked at the level of non-cyclized precursors, as some radioactive lanosterol and ergosterol were detectable on the TLC plates (Table 2). In spheroplasts from all three organisms, the squalene dioxide was completely absent, a result that deserves attention, being the squalene dioxide the usual partner of the squalene monoxide when the latter accumulates in intact cells (Milla et al., 2002b; Mo et al., 2003).

\section{Intact cells and spheroplasts from ERG7 and ERG27 deletant yeast (S. cerevisiae) strains}

ERG7 and ERG27 deletant yeast strains share the absence of oxidosqualene cyclase activity, as (i) the ERG7 deletant strain lacks the enzymatic protein that cyclizes the oxidosqualene, whereas (ii) the ERG27 deletant strain lacks the steroid-3-ketoreductase (EC 1.1.1.270), a protein belonging to the $\mathrm{C} 4$ demethylase complex of sterol biosynthesis that acts as an absolutely-required chaperonine-like protein toward the oxidosqualene cyclase (Mo et al., 2003; Teske et al., 2008). These two strains were included in the study due to their intrinsic propensity to accumulate epoxide derivatives of squalene, a trait similar to that observed in the spheroplasts from wild-type cells. Indeed, intact cells of both strains, incubated with radiolabelled acetate, accumulated radioactive epoxysqualenes, mainly dioxidosqualene (DOS), as expected when oxidosqualene cyclase activity is abolished (Table 2). No significant difference between the two gene-deletant strains was observed. When spheroplasts from both strains were incubated with the radioactive precursor, radioactivity accumulated also into the epox- 

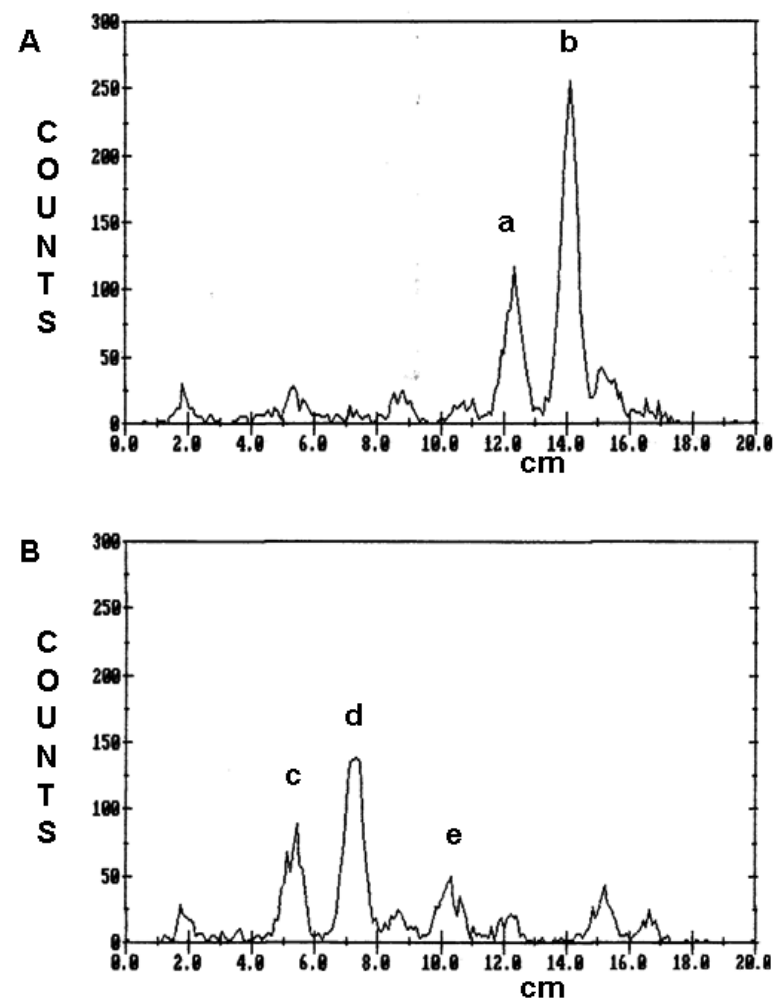

Figure 2. Chemical reduction of non-saponifiable lipid extracted from whole cell of K206A-Erg27p mutant strain.

Radiochromatograms $\mathrm{A}$ ) before reduction, and $\mathrm{B}$ ) after reduction with $\mathrm{NaBH}_{4}$. Peak a: 4,4-desmethylsterone, peak b: 4-monomethylsterone, peak c: $\beta$-hydroxy derivative of 4,4-desmethylsterone, peak $\mathrm{d}$ : $\beta$-hydroxy derivative of 4-monomethylsterone and the a-hydroxy derivative of 4,4-desmethylsterone coeluted, peak e: a-hydroxy derivative of 4-monomethylsterone (Taramino et al., 2010a).

ysqualene fraction, but the mono-/diepoxide ratio appeared dramatically different from intact cells, with the monoepoxide completely predominant over dioxide in spheroplasts.

\section{Intact cells and spheroplasts from R40A-Erg27p and K206A-Erg27p yeast (S. cerevisiae) strains}

The R40A-Erg27p and K206A-Erg27p belong to a group of engineered yeast strains constructed with the aim of separating the catalytic function of Erg27p from its Erg7p chaperone ability (Teske et al., 2008). Unlike ERG27 knockout strains, in these point mutation strains, the chaperone ability of Erg27p toward Erg7p is maintained, thus OSC (Erg7p) does work properly, whereas the keto-reductase activity is substantially reduced. In tracer experiments with intact cells of R40A-Erg27p and K206A-Erg27p grown in the presence of radiolabelled acetate, most radioactivity accumulated into two compounds, chromatographically corresponding to 4-methyl zymosterone and zymosterone on TLC plates (Table 2). The 3-keto nature of the compounds was unambiguous, as seen by treating part of the non-saponifiable extract of K206A-Erg27p yeast strain with $\mathrm{NaBH}_{4}$ before TLC separation; as reported in Fig. 2, the strong reducing agent effectively transformed the original compound into two more polar compounds, presumably the alpha- and beta-hydroxy derivatives (Taramino et al., 2010a). Negligible amounts of other radioactive non-saponifiable lipids, such as squalene and squalene monoxide were detectable on the TLC plates. In spheroplasts, the distribution of radioactivity among the components of the lipid extract changed abruptly with a dramatic increase of squalene. However, a fair amount of a compound chromatographically corresponding to 4-methyl zymosterone was still present (Table 2).

\section{DISCUSSION}

In this report, we are comparing the metabolic flow through the post-squalene section of ergosterol biosynthesis in intact growing cells and spheroplasts from $S$. cerevisiae, $S$. pombe and $P$. pastoris wild-type strains (group 1), as well as from $S$. cerevisiae strains lacking oxidosqualene cyclase (group 2) or steroid-3-keto reductase activity (group 3).

An overall difference that could be observed among the cell lines was that in intact cells the metabolic pathway flows till the end product, whereas in spheroplasts the pathway is detained some step before. Ergosterol was indeed the main radioactive product formed in intact growing cells of different wt yeast strains cultured in the presence of radioactive acetate, whereas in spheroplasts the acyclic intermediates, squalene and oxidosqualene, retained most of the non-saponifiable lipid radioactivity. Apparently, in spheroplasts the sterol biosynthetic flow was kept from entering the complex distal section of the pathway, crowded with steroid-shaped precursors of the end product. Whether this depends on the spheroplasts being cell wall-free or non-proliferating cells (or both) was difficult to establish: indeed, their requirement of ergosterol for new membranes is poor, thus a mechanism of early damping of the metabolic path before the formation of steroid products (hard to address and dispose) may represent a defense strategy. Surprisingly, dioxidosqualene, which usually matches the accumulation of squalene monoepoxide (Nelson et al., 1981; Wong et al., 2008), was absent in spheroplasts from all three wt yeast strains studied. Moreover, in the strains lacking oxidosqualene cyclase activity (group 2), thus endowed with a high propensity to form dioxidosqualene (Milla et al., 2002b; Mo et al., 2003), this compound accumulated exclusively in growing intact cells (till 80\% of the non-saponifiable lipids), being poorly present in spheroplasts. No significant difference was observed between cells lacking oxidosqualene cyclase activity due to the ERG7 gene deficiency and cells in which the protein oxidosqualene cyclase was present but inactive (Milla et al., 2002b). In this kind of cells, DOS may be regarded either as a side product, being a derivative of an intermediate of ergosterol biosynthesis (squalene monoxide), or as an end product of the pathway, with squalene epoxidase being the last functional step of the shortened pathway. In the intact cells, squalene epoxidase seemed to take care of the monoepoxysqualene accumulated in a consequence of the absence of the OSC activity. The unusual "second" epoxidase activity of squalene epoxidase could be attributed either to simple "mass pressure" exerted by the accumulated monoepoxide offering its second epoxidable end, or perhaps to some regulatory role of the enzyme oriented to generate precursors of signaling molecules such as the oxysterols (Beh et al., 2004; Gill et al., 2008). Willing to hazard a guess, the drop in the second epoxidation of squalene monoepoxide in spheroplasts could result from the fading out of such a regulatory machinery in these abnormal cell wall-free non-proliferating cells. In cells from group 3, 
the ergosterol biosynthesis resulted strongly depressed at the level of 3-ketosteroid reductase, one of the enzymes of the C4-demethylation apparatus. Point mutations R40A and K206A caused, each, an almost complete reduction of the catalytic activity of the protein ('Teske et al., 2008), thus determining in intact cells an accumulation of 3-ketosteroids, mainly C4-methyl zymosterone, which therefore represented the end product of the altered pathway. As in wild type cells, also in spheroplasts from these mutants incubated with radioactive acetate, the metabolic flow was hampered at the boundary between cyclized and non-cyclized precursors of ergosterol, resulting from the accumulation of squalene along with methyl zymosterone. Notably, this accumulation was not accompanied by the epoxidation of squalene, as though squalene epoxydase were poorly active in a spheroplast environment.

\section{CONCLUSIONS}

The comparison of the late steps of ergosterol biosynthesis in intact cells and spheroplasts from different yeast strains revealed sharp differences between the two cellular systems, suggesting the occurrence of a complex control over the post-squalene section of the pathway. To our knowledge, this is the first comparison of a metabolic pathway in intact cells and in spheroplasts, and much additional experimental work should be done to explain the observed differences, mainly to establish whether they depend on the absence of the cell wall or on the non- proliferating status of the spheroplasts. We are confident that the extension of the comparison to other lipid pathways will bring interesting surprises, contributing to the unraveling of the complex lipid metabolism network.

\section{Acknowledgements}

Thanks are due to Prof. Espenshade (Johns Hopkins University School of Medicine, Baltimore, MD, USA) for supplying the $S$. pombe strain KGY425.

This work was supported in part by the financial support of the University of Torino [Fondo di Ricerca Locale (ex 60\%) 2013-B] to Simonetta Oliaro-Bosso.

\section{REFERENCES}

Balliano G, Dehmlow H, Oliaro-Bosso S, Scaldaferri M, Taramino S, Viola F, Caron G, Aebi J, Ackermannb J (2009) Oxidosqualene cyclase from Saccharomyces cerevisiae, Trypanosoma cruri, Pneumocystis carinii and Arabidopsis thaliana expressed in yeast: a model for the development of novel antiparasitic agents. Bioorg Med Chem Lett 19: 18-23. http://dx.doi.org/10.1016/j.bmcl.2008.12.040.

Balliano G, Viola F, Ceruti M, Cattel L (1988) Inhibition of sterol biosynthesis in Saccharomyces cerevisiae by $\mathrm{N}, \mathrm{N}$-diethylazasqualene and derivatives. $B B A-$ Mol Cell Biol L 959: 9-19. http://dx.doi. org/10.1016/0005-2760(88)90144-0.

Becker B, Schmitt MJ (2011) Adapting yeast as model to study ricin toxin a uptake and trafficking. Toxins 3: 834-847. http://dx.doi. org/10.3390/toxins3070834.

Beh CT, Rine J (2004) A role for yeast oxysterol-binding protein homologs in endocytosis and in the maintenance of intracellular sterol-lipid distribution. J Cell Sci 117: 2983-2996. http://dx.doi. org/10.1242/jcs.01157.

Daum G, Böhni PC, Schatz G (1982) Import of proteins into mitochondria. Cytochrome $b 2$ and cytochrome $c$ peroxidase are located in the intermembrane space of yeast mitochondria. J BiolChem 257: 13028-13033.

Gill S, Chow R, Brown AJ (2008) Sterol regulators of cholesterol homeostasis and beyond: The oxysterol hypothesis revisited and revised. Prog Lipid Res 47: 391-404. http://dx.doi.org/10.1016/j. plipres.2008.04.002.

Milla P, Viola F, Oliaro-Bosso S, Rocco F, Cattel L, Joubert BM, LeClair RJ, Matsuda SPT, Balliano G (2002a) Subcellular localization of oxidosqualene cyclase from Arabidopsis thaliana, Trypanosoma cruzi, and Pneumocystis carinii expressed in yeast. Lipids 37: 1171-1176. http://dx.doi.org/10.1007/s11745-002-1017-9.

Milla P, Athenstaedt K, Viola F, Oliaro-Bosso S, Kohlwein S, Daum $G$, Balliano G (2002b) Yeast oxidosqualene cyclase (Erg7p) is a major component of lipid particles. J Biol Chem 277: 2406-2412. http://dx.doi.org/10.1074/jbc.M104195200.

Mo C, Milla P, Athenstaedt K, Ott R, Balliano G, Daum G, Bard M (2003) In yeast sterol biosynthesis the 3-keto reductase protein (Erg27p) is required for oxidosqualene cyclase (Erg7p) activity. BBA - Mol Cell Biol L 1633: 68-74. http://dx.doi.org/10.1016/S13881981(03)00088-X.

Nelson JA, Steckbeck SR, Spencer TA (1981) Biosynthesis of 24,25-Epoxycholesterol from squalene 2,3;22,23-dioxide. J Biol Chem 256: 1067-1068.

Oliaro-Bosso S, Viola F, Matsuda S, Cravotto G, Tagliapietra S, Balliano $G$ (2004) Umbelliferone aminoalkyl derivatives as inhibitors of oxidosqualene cyclases from Saccharomyces cerevisiae, Trypanosoma cruri and Pneumocystis carinii. Lipids 39: 1007-1012. http://dx.doi. org/10.1007/s11745-004-1323-2.

Taramino S, Valachovic M, Oliaro-Bosso S, Viola F, Teske B, Bard M, Balliano G (2010a) Interactions of oxidosqualene cyclase (Erg7p) with 3-keto reductase (Erg27p) and other enzymes of sterol biosynthesis in yeast. $B B A-$ Mol Cell Biol L 1801: 156-162. http:// dx.doi.org/10.1016/j.bbalip.2009.10.005.

Taramino S, Teske B, Oliaro-Bosso S, Bard M, Balliano G (2010b) Divergent interactions involving the oxidosqualene cyclase and the steroid-3-ketoreductase in the sterol biosynthetic pathway of mammals and yeasts. BBA-Mol Cell Biol L 1801: 1232-1237. http:// dx.doi.org/10.1016/j.bbalip.2010.07.006.

Teske B, Taramino S, Bhuiyan MSA, Kumaraswami NS, Randall SK, Barbuch R, Eckstein J, Balliano G, Bard M (2008) Genetic analyses involving interactions between the ergosterol biosynthetic enzymes, lanosterol synthase $(\operatorname{Erg} 7 \mathrm{p})$ and 3-ketoreductase (Erg27p), in the yeast Saccharomyces cerevisiae. BBA-Mol Cell Biol L 1781: 359-366. http://dx.doi.org/10.1016/j.bbalip.2008.04.017.

Wilcox LJ, Balderes DA, Wharton B, Tinkelenberg AH, Rao G, Sturley SL (2002) Transcriptional profiling identifies two members of the ATP-binding cassette transporter superfamily required for sterol uptake in yeast. J Biol Chem 277: 32466-32472. DOI http://dx.doi. org/10.1074/jbc.M204707200.

Wong J, Quinn CM, Gelissen IC, Brown AJ (2008) Endogenous $24(S), 25$-epoxycholesterol fine-tunes acute control of cellular cholesterol homeostasis. J Biol Chem 283: 700-707. http://dx.doi. org/10.1074/jbc.M706416200. 